\title{
MANFAAT ASUHAN SWEDISH MASSAGE PADA LANSIA YANG MENGKONSUMSI OLAHAN TOGA DI SAAT PANDEMI COVID-19 TERHADAP STRES LANSIA
}

\author{
Naomi Parmila Hesti Savitri ${ }^{1),}$ Wiwit Desi Intarti' ${ }^{2)}$ \\ ${ }^{1}$ Sekolah Tinggi Ilmu Kesehatan Bakti Utama Pati \\ ${ }^{2}$ Sekolah Tinggi Ilmu Kesehatan Graha Mandiri Cilacap \\ Email: naomisavitri@gmail.com
}

\begin{abstract}
ABSTRAK
Kecemasan yang terjadi pada lansia karena adanya peningkatan kasus di masa pandemic Covid-19 berdampak pada perubahan fisik, ketegangan dan tanda-tanda vital. Upaya mandiri yang dilakukan lansia adalah rutin mengkonsumsi olahan TOGA sebagai upaya peningkatan imunitas. Meskipun terdapat manfaat dari konsumsi olahan TOGA namun tidak signifikan mengatasi keluhan fisik dan kecemasan pada lansia sehingga diperlukan upaya agar lansia tetap rileks dan bugar melalui asuhan Swedish massage. Metode penelitian merupakan eksperimen lapangan dengan rancangan penelitian one group pretest posttest design. Analisis data menggunakan uji paired sample t-test pada CI 95\%. Hasil penelitian menunjukkan dari uji paired samples test $\mathrm{T}_{\text {hitung }}$ systol $=8,004>\mathrm{T}_{\text {tabel }} 2,093$; $\mathrm{T}_{\text {hitung }}$ diastol $=11,159>\mathrm{T}_{\text {tabel }} 2,093 ; \mathrm{T}_{\text {hitung }}$ nadi $=6,676>\mathrm{T}_{\text {tabel }} 2,093 ; \mathrm{T}_{\text {hitung }}$ respirasi $=6,257>\mathrm{T}_{\text {tabel }} 2,093$ nilai signifikansi 2-tailed ( $\mathrm{p}<0.05$ ). Teknik Swedish massage merupakan teknik pemijatan yang akan merangsang saraf eferen untuk melepaskan histamine dan asetilkolin sehingga memberikan reflek vasodilatasi vena, arteriol dan mengurangi aktivitas saraf simpatis sehingga terjadi penurunan resistensi vaskuler perifer yang berdampak pada penurunan tekanan darah dan denyut nadi. Simpulan penelitian adalah terdapat manfaat Swedish massage pada lansia yang mengkonsumsi olahan TOGA saat pandemi covid-19 terhadap stress lansia.
\end{abstract}

Kata kunci: TOGA, Stres lansia, Swedish massage

\begin{abstract}
Anxiety that occurs in the elderly due to an increase in cases during the Covid-19 pandemic has an impact on physical changes, tension and vital signs. Independent efforts made by the elderly are routinely consuming processed TOGA as an effort to increase immunity. Although there are benefits from consuming processed TOGA, it is not significant in overcoming physical complaints and anxiety in the elderly so that efforts are needed to keep the elderly relaxed and fit through Swedish massage care. The research method is a field experiment with a one group pretest posttest design. Data analysis used paired sample t-test at $95 \%$ CI. The results showed that from the paired samples test Tcount systolic $=8.004>$ Ttable 2.093; Tcount diastolic $=11,159>$ Ttable 2,093; Pulse count=6,676 > Ttable 2,093; Tcount respiration=6,257>Ttable 2,093 2-tailed significance value ( $p<$ 0.05). The Swedish massage technique is a gentle massage technique starting from the blood of the legs to the back and head that will stimulate the efferent nerves to release histamine and acetylcholine so as to provide reflex vasodilation of veins, arterioles and reduce sympathetic nerve activity resulting in a decrease in peripheral vascular resistance which has an impact on decreasing blood pressure. and pulse. The conclusion of the study is that there are benefits of Swedish massage for the elderly who consume TOGA preparations during the covid-19 pandemic on elderly stress.
\end{abstract}

Keywords: TOGA, Elderly stress, Swedish massage 


\section{PENDAHULUAN}

Penyakit COVID-19 (Corona virus Disease-19) adalah penyakit menular yang disebabkan oleh evere acute respiratory syndrome coronavirus 2 (SARS-CoV-2). Berbagai aspek kehidupan telah terdampak dengan adanya Pandemi COVID-19 ini. Ancaman penyakit semakin meningkat karena banyak masyarakat yang belum sadar akan bahaya yang dapat menyerang siapa saja terutama pada kelompok umur tua atau lanjut usia. Lanjut usia menghadapi risiko yang signifikan terkena penyakit virus Corona ini, karena mereka mengalami gangguan kesehatan seiring dengan penurunan kondisi fisiologi.

Sesuai Peraturan Menteri Kesehatan Republik Indonesia Nomor 25 Tahun 2016 tentang Rencana Aksi Nasional Kesehatan Lanjut Usia Tahun 2016-2019, bahwa pemerintah memfasilitasi pengembangan kelompok lanjut usia serta berupaya melakukan pemeliharaan kesehatan bagi lanjut usia bertujuan untuk menjaga agar para lanjut usia tetap sehat, mandiri dan produktif secara sosial dan ekonomi.

Usia lanjut adalah seseorang yang berusia 60 tahun atau lebih, yang secara fisik terlihat berbeda dengan kelompok umur lainnya (Depkes RI, 2003). Menurut rumusan WHO, batasan lanjut usia sebagai berikut: Usia pertengahan (middle age) yaitu antara usia 45 - 59 tahun, Lanjut usia (elderly) yaitu antara usia 60 - 74 tahun, Lanjut usia tua (old) yaitu antara usia 75 - 90 tahun, Usia sangat tua (very old) yaitu di atas usia 90 tahun.

WHO menyebutkan, lebih dari 95\% kematian akibat Virus Corona terjadi pada penduduk usia lebih dari 60 tahun. Lebih dari $50 \%$ dari semua kematian melibatkan terjadi pada mereka yang berusia 80 tahun atau lebih. Menurut laporan WHO dapat dilihat bahwa 8 dari 10 kematian terjadi pada individu dengan setidaknya satu komorbiditas, khususnya mereka dengan penyakit kardiovaskular, hipertensi dan diabetes mellitus, tetapi juga dengan berbagai kondisi kronis lainnya (Kemenpemberdayaan perempuan dan perlindungan anak RI, 2020).

Selain gangguan sistem imun, tidak sedikit lansia yang memiliki penyakit kronis, seperti penyakit jantung, diabetes, asma, atau kanker. Hal ini bisa meningkatkan risiko atau bahaya infeksi virus Corona. Dan komplikasi yang timbul akibat COVID-19 juga akan lebih parah bila penderitanya sudah memiliki penyakit-penyakit tersebut bahkan bisa sampai menyebabkan kematian.

Kabupaten Pati merupakan salah satu wilayah yang berada di Jawa Tengah dan termasuk 8 (delapan) daerah yang dalam kondisi zona merah atau mempunyai tingkat resiko penularan virus Corona yang tinggi. dengan kasus penyebarab Covid-19 sebanyak 175 warga Pati yang dirawat dan 444 warga Pati yang meninggal dunia selama kurun waktu 2 bulan pada bulan Mei dan Juni 2021, dan dalam kurun waktu 3 (tiga) hari bisa mencapa belasan jenazah yang dikuburkan per harinya (DKK Pati, 2021)

Banyaknya data yang menyebutkan tentang peningkatan kasus Covid-19. menyebabkan kondisi kecemasan dan stress pada kelompok lansia. Stress lansia disebabkan karena adana kecemasan rentan terserang berbagai penyakit termasuk yang disebabkan oleh virus Corona. Kecemasan adalah suatu kekhawatiran atau ketegangan yang berasal dari sumber yang tidak diketahui menurut Freud kecemasan adalah situasi yang tidak menyenangkan yang menumbukkan perasaan yang tidak menyenangakan yang mana perasaan tersebut tidak dapat dipastikan namun dapat dirasakan (Intarti dan Savitri, 2021).

Menurut Wahyuningsih, dkk (2011) stres terjadi apabila stresor tersebut dirasakan dan dipersepsikan sebagai ancaman sehingga menimbulkan kecemasan yang merupakan awal dari gangguan kesehatan fisik dan psikologis. Stresor adalah variabel yang dapat diidentifikasi sebagai penyebab timbulnya stres. Sumber stres dapat berasal dari dalam tubuh dan luar tubuh. Salah satu jenis stresor adalah stresor biologic yang dapat berupa bakteri, virus, hewan, binatang, tumbuhan, dan berbagai macam makhluk hidup yang dapat mempengaruhi kesehatan. Stres mengacaukan hormon di dalam tubuh, membuat cemas, dan mudah marah. Jika stres dibiarkan maka akan membuat beban fisik ikut terpengaruh karena adanya penurunan imunitas.

Kecemasan akan direspon pada beberapa perubahan pada tubuh terutama perubahan tanda-tanda vital berupa peningkatan tekanan darah, denyut nadi dan pernafasan. Jika terjadi kecemasan yang terlalu berlebihn maka kerja jantung dan kebutuhan 
oksigen juga akan meningkat (American Heart Assosiation, 2015).

Menurut data Organisasi Kesehatan Dunia (WHO), angka harapan hidup masyarakat Indonesia di tahun 2016 yaitu 60,4 tahun untuk pria dan 63 tahun untuk wanita. Populasi manusia lanjut usia (manula) secara statistik menunjukkan jumlah yang signifikan dalam populasi penduduk di Indonesia. Jumlah manula perempuan lebih banyak dibandingkan dengan manula laki-laki. Makin bertambah usia, makin besar kemungkinan seseorang mengalami permasalahan fisik, jiwa, spiritual, ekonomi dan sosial. Salah satu permasalahan yang sangat mendasar pada lanjut usia adalah masalah kesehatan akibat proses degeneratif, hal ini ditunjukkan oleh data pola penyakit pada lanjut usia (WHO, 2020)

Kondisi psikologi masa lansia antara laki-laki dan perempuan sangat berbeda terutama dalam menghadapi masalah. Dalam menghadapi masalah, lansia perempuan lebih cenderung mudah depresi karena perempuan cenderung memiliki pengetahuan yang lebih detail daripada laki-laki sehingga justru berpengaruh pada tingkat kecemasan yang lebih besar dibanding lansia laki-laki (Jahja Y, 2011)

Menurut BPS (2019) Angka Harapan Hidup Perempuan adalah 73,33 tahun. Salah satu hal yang mempengaruhi angka harapan hidup seseorang yaitu gaya hidup yang dijalani. Untuk memperpanjang angka harapan hidup, ada beberapa gaya hidup sehat yang sebaiknya diterapkan dalam keseharian antara lain menjauhkan diri dari stres, berolahraga, cukup istirahat, berhenti merokok, makan makanan bergizi seimbang

Tanaman Obat Keluarga (TOGA) merupakan pengobatan olahan tradisional yang digunakan sebagai pengobatan alternative. Penggunaan TOGA yang merupakan hasil budidaya rumahan telah membawa khasiat sebagai obat untuk upaya preventif dan promotif termasuk upaya kuratif. Dengan mengkonsumsi jamu rimpang-rimpangan bisa dijadikan alternative untuk meningkatkan imunitas dalam mencegah virus Corona (Pertiwi dkk, 2020).

Bahan yang tersimpan dalam jamu rimpang-rimpangan yang disarankan untuk dikonsumsi sebagai upaya meningkatkan imunitas adalah golongan zingibereceae yang terdiri dari jahe, temulawak, kunyit, kencur dan lengkuas. Jamu rimpang-rimpangan mempunyai fungsi untuk metabolisme tubuh, sebagai antiradang dan antiinflamsi yang terkandung dalam jahe berupa senyawa gingerol dan shogaol, curcumin pada kunyit dan tumerol pada temulawak. Bahan-bahan tersebut memiliki kandungan antioksidan yang tahan pemanasan sehingga aman dikonsumsi (Suparmi dan Wulandari A, 2012).

Masyarakat sudah banyak mengenal TOGA dan olahannya untuk mencegah penularan virus Covid-19 terutama lansia yang sudah melakukan kegiatan tersebut secara turun temurun. Berdasarkan studi pendahuluan yang dilakukan kepada 5 orang lansia menyatakan bahwa mereka rutin mengkonsumsi olahan TOGA karena merupakan obat tradisional turun temurun. Namun kondisi pandemic Covid-19 tetap membuat mereka cemas dan stress karena takut terkena penyakit yang berat sehingga manfaat yang didapat setelah mengkonsumsi olahan TOGA masih merasakan keluhan penyakit yang pernah dirasakan kadang kambuh.

Stres lansia tidak boleh terjadi terlalu lama. Stres dalam bentuk kecemasan yang dialami lansia bisa menimbulkan kondisi penurunan status fungsional, serangan akut, gejala hipertensi, gejala ulkus lambung, bahkan sampai kondisi iritabilitas usus. Oleh karena itu perlu segera dilakukan berbagai hal menyenangkan untuk mengatasinya. Cara mengatasi stres yang dilakukan selain memberikan olahan TOGA maka dilakukan dengan asuhan Swedish massage kepada lansia.

Menurut Ritanti dan Sari (2019) Swedish Massage adalah manipulasi pada jaringan tubuh mulai dari kaki sampai ke punggung dengan teknik khusus untuk mempersingkat waktu pemulihan dari ketegangan otot (kelelahan), meningkatkan sirkulasi darah tanpa meningkatkan beban kerja jantung, meregangkan otot ligament dan tendon seklaigus menenangkan pada saat yang bersamaan serta menstimulasi kulit dan jaringan saraf.

Hasil penelitian menyebutkan bahwa melakukan pemijatan untuk membuat tubuh tenang dan rileks dapat mencegah terjadinya hipertensi. Hal tersebut dapat dilakukan melalui pijat kaki dan punggung selama 10-15 menit selama 3 hari yang dapat mempengaruhi 
penurunan tekanan darah systole dan diastole melalui mekanisme dari mekanoreseptor tubuh yang mengatur tekanan sentuhan dan kehangatan menjadi mekanisme relaksasi. Mekanoreseptor merupakan sel yang menyampaikan sinyal ke system saraf pusat dan mentransduksi rangsangan mekanik (Alikin dkk, 2014).

Indonesia saat ini sedang menerapkan upaya untuk meningkatkan angka harapan hidup menggunakan asuhan komplementer. Asuhan komplementer terbagi dalam 2 kelompok besar yaitu pelayanan kesehatan tradisional ramuan dan pelayanan kesehatan tradisional keterampilan (Windaryanti dan Riska, 2019).

Masalah stres para lansia membutuhkan pelayanan kesehatan, oleh karena itu perlu dikembangkan pelayanan kesehatan yang lebih mengutamakan upaya pencegahan, dan pemeliharaan kesehatan disamping upaya penyembuhan dan pemulihan yang dapat dilakukan melalui asuhan komplementer yang aman.

Swedish massage merupakan salah satu terapi komplementer yaitu cara penanggulangan penyakit yang dilakukan sebagai pendukung pengobatan medis konvensional atau sebagai pengobatan pilihan lain diluar pengobatan medis yang konvensional. Prinsip dari terapi komplementer adalah terapi yang diberikan sebagai pelengkap dari standar asuhan pelayanan kebidanan yang berlaku.

Tujuan penelitian ini adalah untuk mengetahui manfaat asuhan Swedish massage pada lansia yang mengkonsumsi olahan TOGA di saat pandemi Covid-19 terhadap stress lansia di Desa Blaru Kecamatan Pati Kabupaten Pati.

\section{METODE PENELITIAN}

Penelitian ini dilaksanakan di desa Blaru, kecamatan Pati yang merupakan salah satu wilayah yang terkonfirmasi kasus Covid19 di Kabupaten Pati. Populasi dalam penelitian ini adalah seluruh kelompok wanita lanjut usia di wilayah Desa Blaru yang terkonfirmasi Covid-19 di Kabupaten Pati sebanyak 124 lansia. Sampel dalam penelitian ini dilakukan secara acak dengan teknik random sampling dengan kriteria rutin mengkonsumsi olahan TOGA minimal satu minggu sekali selama masa pandemic Covid-
19., dan jumlah sample dalam penelitian ini adalah sebanyak 54 ibu lansia.

Data penelitian merupakan data primer yaitu melalui intervensi asuhan dan observasi langsung sebelum dan sesudah dilakukan Swedish massage, serta data sekunder melalui kuesioner tentang frekuensi konsumsi olahan TOGA selama Pandemi Covid-19 dan manfaat setelah mengkonsumsi olahan TOGA yang dirasakan lansia.

Jenis penelitian merupakan penelitian eksperimen lapangan dengan rancangan penelitian one group pretest posttest design. Penelitian ini merupakan intervensi analitik untuk mengetahui manfaat Swedish massage pada lansia yang mengkonsumsi olahan TOGA saat pandemi covid-19 terhadap stress lansia. Asuhan Swedish massage dilakukan 2 kali seminggu selama 2 minggu kemudian dievaluasi perubahan stress melalui pengukuran tanda-tanda vital.

Prosedur asuhan dalam penelitian ini adalah wanita lansia yang terpilih dilakukan tindakan Swedish massage. Pemijatan dilakukan dengan posisi berbaring dan dimulai dari kaki lalu berlanjut ke paha, pinggang, punggung, tangan, bahu, leher, kepala dan wajah. Pemijatan dilakukan peneliti selama 30 menit menggunakan hand and body lotion dan minyak zaitun serta minyak penghangat aromatic untuk pelicin saat memijat dan menghangatkan badan. Pengukuran tekanan darah systole dan diastole, nadi dan pernafasan dilakukan sebelum dan sesudah dilakukan tindakan dan hasil pengukuran dicatat dalam lembar observasi.

Uji statistik yang digunakan adalah uji paired sample t-test untuk mengetahui ada tidaknya perbedaan tekanan darah systole, diastole, nadi dan pernafasan sebelum dan sesudah dilakukan Swedish massage pada tingkat kepercayaan $95 \%$ dimana taraf signifikansi sebesar 0,05 , sehingga bila ditemukan hasil analisis statistik $\mathrm{p}<0,05$ maka variabel di atas dinyatakan berhubungan secara signifikan.

\section{HASIL}

Hasil penelitian univariat menunjukkan karakteristik subyek penelitian seperti yang disajikan pada tabel berikut ini. 
Tabel 1. Distribusi Karakteristik Responden

\begin{tabular}{|c|c|c|c|}
\hline No & Karakteristik & $\mathbf{n}$ & $\%$ \\
\hline \multirow[t]{4}{*}{1.} & Usia (tahun) & & \\
\hline & $45-59$ & 10 & 18 \\
\hline & $60-74$ & 20 & 37 \\
\hline & $75-90$ & 24 & 44 \\
\hline \multirow[t]{4}{*}{2.} & Penyakit yang diderita & & \\
\hline & Hipertensi & 15 & 28 \\
\hline & Diabetes Melitus & 21 & 39 \\
\hline & Asam Urat & 18 & 33 \\
\hline \multirow[t]{3}{*}{3.} & Kejenuhan dengan sitausi pandemic & & \\
\hline & Jenuh & 45 & 83 \\
\hline & Tidak jenuh & 9 & 17 \\
\hline \multirow[t]{4}{*}{4.} & Kegiatan sehari-hari & & \\
\hline & Berkebun & 5 & 9 \\
\hline & Social keagamaan & 4 & 6 \\
\hline & Berdiam diri & 45 & 83 \\
\hline
\end{tabular}

Berdasarkan tabel 1 menunjukkan karakteristik lansia berdasarkan usia yaitu kelompok usia 45-59 tahun berjumlah 10 orang (18\%), kelompok usia 60-74 tahun berjumlah 20 orang $(37 \%)$ dan kelompok usia 75-90 tahun berjumlah 24 orang (44\%). Jenis penyakit yang diderita lansia menunjukkan lansia yang menderita hipertensi sebanyak 15 orang (28\%), diabetes mellitus sebanyak 21 orang (39\%),

Tabel 2. Frekuensi Lansia Mengkonsumsi TOGA selama Pandemi

\begin{tabular}{clcc} 
No & \multicolumn{1}{c}{ Frekuensi } & n & $\%$ \\
\hline 1. & Setiap hari & 9 & 17 \\
& 3 x / minggu & 19 & 35 \\
& 1 x/minggu & 26 & 48 \\
& Jumlah & 54 & 100 \\
\hline Berdasarkan tabel 2 menunjukkan & setiap hari sebanyak 9 orang (17\%), 3 kali \\
bahwa frekuensi mengkonsumsi olahan TOGA & seming sebanyak 19 orang (35\%) dan 1 \\
selama pandemi yang dilakukan oleh lansia & minggu sekali sebanyak 26 orang (48\%).
\end{tabular}

Tabel 3. Distribusi Keluhan Lansia Sebelum dan Sesudah Swedish Massage.

\begin{tabular}{|c|c|c|c|c|c|}
\hline \multirow[t]{2}{*}{ No } & \multirow[t]{2}{*}{ Karakteristik } & \multicolumn{2}{|c|}{ Sebelum } & \multicolumn{2}{|c|}{ Sesudah } \\
\hline & & $\mathbf{n}$ & $\%$ & $\mathbf{n}$ & $\%$ \\
\hline \multirow[t]{7}{*}{1.} & Keluhan Fisik & & & & \\
\hline & Cepat lelah & 9 & 17 & 2 & 4 \\
\hline & Kaku leher & 11 & 21 & 3 & 6 \\
\hline & Mudah flu & 27 & 50 & 12 & 22 \\
\hline & Nyeri ekstremitas & 3 & 6 & 1 & 2 \\
\hline & Tidak ada & & & & \\
\hline & keluhan & 0 & 0 & 36 & 66 \\
\hline \multirow[t]{3}{*}{2.} & Insomnia & & & & \\
\hline & Sering gangguan & 26 & 48 & 0 & 0 \\
\hline & $\begin{array}{l}\text { Kadang } \\
\text { terganggu }\end{array}$ & 15 & 28 & 6 & 11 \\
\hline
\end{tabular}


Tidak terganggu

3. Kecemasan psikis

terhadap kondisi

pandemi

Cemas

Tidak cemas

Berdasarkan tabel 3 menunjukkan perbedaan prosentase bermakna sebelum dan sesudah dilakukan asuhan Swedish massage yaitu yang awalnya menyatakan cepat lelah sebanyak 9 orang $(17 \%)$ berubah menjadi 2 orang (4\%), kaku leher sebanyak 11 orang $(21 \%)$ menjadi 3 orang $(6 \%)$, mudah flu sebanyak 27 orang (50\%) menjadi 12 orang (22\%), nyeri ekstremitas sebanyak 3 orang $(6 \%)$ menjadi 1 orang $(2 \%)$ dan setelah dilakukan intervensi yang merasakan tidak ada keluhan sebanyak 36 orang (66\%). Untuk keluhan Tabel 4. Hasil analisis Paired Sample Statistic sebelum dan sesudah Swedish massage

\begin{tabular}{|c|c|c|c|c|}
\hline \multirow{3}{*}{$\begin{array}{l}\text { Systolsblm } \\
\text { Systolssdh }\end{array}$} & Mean & $\mathrm{N}$ & Std. Deviation & Std. Error Mean \\
\hline & 132.78 & 54 & 18.162 & 2.472 \\
\hline & 123.15 & 54 & 11.002 & 1.497 \\
\hline \multirow{2}{*}{$\begin{array}{l}\text { Diastolsblm } \\
\text { Diastolssdh }\end{array}$} & 85.37 & 54 & 9.052 & 1.232 \\
\hline & 76.11 & 54 & 6.270 & .853 \\
\hline \multirow{2}{*}{$\begin{array}{l}\text { Nadisblm } \\
\text { Nadissdh }\end{array}$} & 83.46 & 54 & 4.355 & .593 \\
\hline & 80.91 & 54 & 2.535 & .345 \\
\hline \multirow{2}{*}{$\begin{array}{l}\text { RRsblm } \\
\text { RRssdh }\end{array}$} & 24.93 & 54 & 2.441 & .332 \\
\hline & 23.20 & 54 & 1.805 & .246 \\
\hline
\end{tabular}

Berdasarkan tabel 4 menunjukkan bahwa terdapat perbedaan rata-rata sebelum dan sesudah dilakukan asuhan Swedish massage yaitu rata-rata penurunan tekanan darah systole dan dan diastole adalah $10 \mathrm{mmHg}$, dan penurunan nadi dan respirasi.

Tabel 5. Hasil Analisis Paired Sample Correlation sebelum dan sesudah asuhan Swedish massage

\begin{tabular}{|c|c|c|c|c|c|c|c|c|}
\hline \multicolumn{5}{|c|}{ N } & Correlation & \multicolumn{3}{|c|}{ Sig. } \\
\hline \multicolumn{4}{|c|}{ Systolsblm \& Systolssdh } & 54 & .933 & & & .000 \\
\hline \multicolumn{4}{|c|}{ Diastolsblm \& Diastolssdh } & 54 & .741 & & & .000 \\
\hline \multicolumn{4}{|c|}{ Nadisblm \& Nadissdh } & 54 & .792 & & & .000 \\
\hline \multicolumn{4}{|c|}{ RRsblm \& RRssdh } & 54 & .582 & & & .000 \\
\hline \multicolumn{9}{|c|}{$\begin{array}{ll}\text { Berdasarkan tabel } 5 \text { menunjukkan } & \text { hubungan } 1 \\
\text { bahwa korelasi tekanan darah systole yaitu } 0,9 & \text { pernapasan } \\
\text { yang menunjukkan hubungan sangat kuat dan } & \text { hubungan } \\
\text { positif, tingkat korelasi tekanan darah diastole } & \text { variabel d } \\
\text { serta nadi yaitu 0,7 yang menunjukkan } & \text { pada level } \\
\text { Tabel 6. Hasil Analisis } \text { Paired Sample Test Sebelum dan Sesudah } S\end{array}$} \\
\hline & \multicolumn{8}{|c|}{ Paired Differences } \\
\hline & Mean & $\begin{array}{c}\text { Std. } \\
\text { Deviation }\end{array}$ & $\begin{array}{l}\text { Std. Error } \\
\text { Mean }\end{array}$ & \multicolumn{2}{|c|}{$\begin{array}{l}\text { 95\% Confidence Interval } \\
\text { of the Difference }\end{array}$} & $\mathrm{t}$ & $\mathrm{df}$ & Sig. (2-tailed) \\
\hline \multirow{2}{*}{$\begin{array}{l}\text { Systolsblm - } \\
\text { Systolssdh } \\
\text { Diastolsblm }\end{array}$} & 9.630 & 8.841 & 1.203 & $\begin{array}{l}\text { Lower } \\
7.217\end{array}$ & $\begin{array}{r}\text { Upper } \\
12.043\end{array}$ & 8.004 & 53 & .000 \\
\hline & 9.259 & 6.097 & .830 & 7.595 & 10.923 & 11.159 & 53 & .000 \\
\hline
\end{tabular}




\begin{tabular}{lllllllll}
\hline Diastolssdh & & & & & & & \\
Nadisblm - & 2.556 & 2.813 & .383 & 1.788 & 3.323 & 6.676 & 53 & .000 \\
$\begin{array}{l}\text { Nadissdh } \\
\text { RRsblm - RRssdh }\end{array}$ & 1.722 & 2.023 & .275 & 1.170 & 2.274 & 6.257 & 53 & .000 \\
\hline
\end{tabular}

Berdasarkan tabel 6 menunjukkan tekanan darah systole dan diastole, nadi dan pernapasan menunjukkan nilai $\mathrm{T}_{\text {hitung }}>\mathrm{T}_{\text {tabel }}$ 2,093 dengan taraf signifikansi (2-tailed) adalah $0,000(\mathrm{p}<0,05)$ maka Ho ditolak dan Ha diterima yaitu terdapat perbedaan tekanan darah systole dan diastole, nadai dan pernapasan sebelum dan sesudah dilakukan asuhan Swedish massage terhadap stress lansia.

\section{PEMBAHASAN}

Berdasarkan karakteristik lansia yang telah mengkonsumsi olahan TOGA seperti yang tertera pada tabel 1 banyak ditemukan pada kelompok lansia usia diatas 60 tahun. Lanjut usia adalah seseorang yang berusia 60 tahun atau lebih yang secara fisik berbeda dengan kelompok umur lainnya Semakin bertambah usia maka kemungkinan seseorang akan mengalami masalah fisik, jiwa, spiritual dan sosial akibat dari proses degenerative yang ditunjukkan pada pola penyakit pada lansia.

Penyakit yang diderita kelompok lansia dalam penelitian ini menderita hipertensi, DM dan asam urat. Dalam kondisi lansia, sistem imun sebagai pelindung tubuh tidak bekerja semaksimal saat masih usia muda. Lansia yang mempunyai penyakit kronis dapat meningkatkan resiko terpapar virus Corona yang dapat menyebabkan gangguan fungsi paru-paru dan organ tubuh yang lain sehingga dapat memperparah kondisi penderita bahkan sampai mengakibatkan kematian (Intarti dan Savitri, 2021).

Berdasarkan kejenuhan kelompok lansia dengan suasana pandemi mzaka sebanyak $83 \%$ lansia merasakan jenuh dan kegiatan sehari-hari yang dilakukan cenderung berdiam diri. Lansia yang lebih banyak berdiam diri dengan minimal aktifitas dapat menurunkan fungsi tubuh.

Orang yang mempunyai kesibukan seharihari yang cenderung aktif dan produktif maka akan memberikan kebugaran dan menghilangkan kejenuhan sehingga pikiran tenang dan fresh. Aktivitas fisik akan memproduksi oksigen sehingga meningkatkan kerja mitokondria untuk menghasilkan energy yang dibutuhkan untuk kelangsungan hidup sel tubuh (Guyton \& Hall, 2007)

Berdasarkan frekuensi konsumsi olahan TOGA, oleh kelompok lansia pada tabel 2 menunjukkan bahwa frekuensi mengkonsumsi TOGA ada yang setiap hari sampai seminggu sekali. Konsumsi TOGA secara rutin dapat membantu meningkatkan system imun tubuh Jamu rimpang-rimpangan mempunyai fungsi untuk metabolisme tubuh, sebagai antiradang dan antiinflamsi yang terkandung dalam jahe berupa senyawa gingerol dan shogaol, curcumin pada kunyit dan tumerol pada temulawak. Bahan-bahan tersebut memiliki kandungan antioksidan yang tahan pemanasan sehingga aman dikonsumsi (Suparmi dan Wulandari A, 2012).

Kondisi mengkonsumsi olahan TOGA bukan untuk menyembuhkan penyakit namun hanya untuk meningkatkan kekebalan tubuh sebagai terapi penunjang (promotif) dan pencegahan (preventif) sehingga perlu didukung adanya aktivitas fisik untuk meningkatkan kebugaran (Nurlila dan Fua, 2020)

Berdasarkan hasil pada tabel 3 menunjukkan pada kondisi sebelum dan sesudah diberikan asuhan Swedish massage, lansia mengalami kondisi keluhan fisik, insomnia dan kecemasan. Namun setelah dilakukan asuhan Swedish massage keluhan fisik, insomnia dan kecemasan mengalami penurunan secara signifikan.

Kondisi stress pada seseorang dapat dibagi menjadi keluhan somatik, psikis dan gangguan psikomotor dengan atau tanpa gejala psikotik. Keluhan somatik dapat berupa nyeri dada atau jantung berdebar-debar, gangguan tidur (insomnia), nyeri otot, sedih dan merasa bersalah, selalu tegang dan suka menyendiri. Sedangkan gangguan psikomotor dapat berupa kurang bersemangat, mudah lupa dan kurang konsentrasi (Intarti, dkk, 2018).

Swedish massage merupakan teknik pijatan lurus memanjang pada otot yang berfokus pada fleksibilitas dan gerakan sendi. 
Gerakan yang dilakukan pada pijatan ini berupa gerakan ringan dengan cara kneading (meremas), friction (gesekan lembut), stretching (peregangan), dan tapping (pukulan-pukulan lembut) yang bertujuan memberikan kenyamanan dan relaksasi otot tubuh karena kelancaran sirkulasi darah. Gerakan pijatan ini berbeda dengan deep massage yang dapat meninggalkan rasa kaku pada tubuh (Ritanti dan Sari, 2019)

Teknik Swedish massage dilakukan selama 30 atau 60 menit menyesuaikan kondisi tubuh kemudian dilakukan mengikuti gerakan dari system peredaran darah dengan melakukan usapan lembut tubuh yang menuju ke jantung serta menghilangkan sisa metabolisme berupa asam laktat di anggota tubuh dengan melemaskan simpul otot atau jaringan tubuh yang disebut adhesi sehingga pijatan ini juga dapat berperan dalam proses detoksifikasi (Widaryanti dan Riska, 2019).

Berdasarkan hasil analisis data menunjukkan terjadi perubahan rata-rata tekanan darah systole dan diastole, nadi dan pernafasan lansia setelah dilakukan asuhan Swedish massage. Kondisi stress dapat mempengaruhi kerja jantung dengan meningkatkan kerja hormone adrenalin sehingga terjadi peningkatan aliran darah dalam tubuh yang berefek pada meningkatnya getaran pada pembuluh darah akibat kontraksi ventrikel kiri. Kondisi cemas akan dipersepsikan oleh indera ke system limbic dan RAS (Reticular Activating Sistem) yang dilanjutkan ke hipotalamus dan hipofisis. Medulla kelenjar adrenal akan mensekresikan norepineprin dan epinefrin yang menyebabkan vasokonstriksi pembuluh darah sehingga terjadi peningkatan denyut nadi dan tekanan darah. (Supa'at dkk, 2013)

Dalam kondisi kecemasan maka peningkatan tekanan darah dan nadi hanya bersifat sementara, selama hormone stress dapat dihilangkan maka tekanan darah dan denyut nadi akan turun kembali mendekati normal. Oleh karena itu perlunya dilakukan asuhan Swedish massage yang berfungsi untuk melancarkan sirkulasi dengan membuat vasodiltasi pembuluh darah.

Hasil analisis korelasi terhadap perubahan tekana darah, denyut nadi dan pernafasan berdasarkan tabel 5 menunjukkan hubungan yang kuat dan positif dan sangat bermakna. Hal tersebut bermakna bahwa pemberian asuhan Swedish massage sangat berpengaruh pada penurunan tekana darah, denyut nadi dan pernafasan lansia.

Berdasarkan hasil perbedaan manfaat sebelum dan sesudah pemberian asuhan Swedish massage pada tabel 6 dapat disimpulkan bahwa terdapat manfaat Swedish massage terhadap kecemasan lansia $(\mathrm{p}<0,005)$ ditandai dengan adanya perubahan systole,diastole denyut nadi dan pernafasan.

Kecemasan yang terjadi pada lansia salah satunya ditandai dengan perubahan keseimbangan di dalam tubuh (homeostatis). Perubahan yang terjadi mengakibatkan terganggunya sirkulasi darah perubahan tekanan darah dan nadi. Ketika tekanan darah meningkat atau menurun itu merupakan suatu tanda dimana sirkulasi darah seseorang sedang bermasalah. Ketika sirkulasi darah menjadi tidak memadai lagi, maka system transport oksigen, karbondioksida, dan hasil-hasil metabolisme lainnya akan terganggu (Wahyuningsih dkk, 2011).

System imunitas dimasa lansia tidak seoptimal saat masih muda, sehingga lansia mudah terserang penyakit termasuk paparan virus covid-19. Upaya untuk menghilangkan stress dan cemas salah satunya adalah dengan memberikan terpai Swedish massage yang bertujuan selain membuat rileks juga dapat membuat tubuh kembali bugar sehingga system imun akan meningkat.

Teknik Swedish massage merupakan teknik pemijatan lembut mulai dari darah kaki sampai dengan punggung dan kepala. Dengan adanya pemijatan mulai dari daerah kaki dan punggung maka akan merangsang saraf eferen untuk melepaskan histamine dan asetilkolin sehingga memberikan reflek vasodilatasi vena, arteriol dan mengurangi aktivitas saraf simpatis sehingga terjadi penurunan resistensi vaskuler perifer yang berdampak pada penurunan tekanan darah (Supa'at dkk, 2019).

Hasil penelitian menunjukkan bahwa Swedish Massage Therapy (SMT) merupakan suatu metode pemijatan yang dilakukan pada permukaan seluruh tubuh. SMT efektif dalam 
penurunan tekanan darah pada ibu dengan hipertensi. Pada tekanan darah sistole terjadi penurunan sebesar $12 \mathrm{mmhg}$ dan penurunan diastole sebesar 5 mmhg (Intarti dkk, 2018).

\section{SIMPULAN}

Konsumsi olahan TOGA oleh lansia meskipun sudah dilakukan secara rutin, namun masih menimbulkan kondisi stress yang ditandai dengan adanya gangguan fisik, kecemasan dan perubahan tanda-tanda vital. Hal ini disebabkan karena olahan TOGA tidak untuk penyembuhan penyakit namun hanya membantu terapi sebagai upaya promotif dan preventif ditambah dengan lansia cenderung berdiam diri tanpa melakukan aktifitas sehingga meningkatkan kejenuhan dan menurunkan kebugaran.

Pemberian asuhan Swedish massage memberikan perbedaan manfaat sebelum dan sesudah diberikan asuhan terhadap stress lansia yang ditandai dengan lansia semakin rilek dan bugar yang ditunjukkan dengan perubahan tanda-tanda vital mendekati normal.

\section{SARAN}

Diharapkan untuk memberikan edukasi dan pelatihan pada masyarakat tentang teknik Swedish massage untuk menurunkan stress sehingga terjadi peningkatan imunitas karena terbukti efektif terhadap penurunan tanda-tanda vital mendekati normal dan kecemasan.

Peneliti berikutnya dapat mengkombinasikan metode pemberian olahan TOGA dan Swedish massage yang dilakukan oleh keluarga atau orang terdekat pada kelompok lansia dengan frekuensi konsumsi yang telah ditentukan dan mengontrol pengaruh dari faktor lain.

\section{DAFTAR PUSTAKA}

Alikin, A., Nuraeni, A., dan Supriyono, M. (2014). Pengaruh Back Massage dengan Aromaterapi Lavender Terhadap Penurunan Tekanan Darah pada Lansia Hipertensi di Desa Kedungasri Kecamatan Ringinarum. Jurnal Ilmu Keperawatan dan Kebidanan.

American Heart Association. All About Heart Rate (Pulse). American Heart Association; 2015.
http://www.heart.org/HighBloodPressure/Rat ePulse Article.

Andria AR, 2018, Pengaruh Pijat kaki dan Punggung terhadap Tingkat Tekanan Darah pada Lansia di Panti Wredha Daerah Surakarta, Skripsi Fakultas Ilmu Kesehatan Universitas Muhammadiyah Surakarta

Badan Pusat Statistika. (2017). Statistik Penduduk Lanjut Usia, https://doi.org/10.1017/CBO9781107415324. 004

Dinas Kesehatan Kabupaten Pati, 2021, Covid19.patikab.go.id

Guyton \& Hall. 2007. Buku ajar fisiologi kedokteran. Edisi II. Jakarta : EGC.

Intarti WD, Puspita L, Oktaviani AS, 2018, Efektifitas Swedish Massage Therapy (SMT) pada Ibu Lansia sebagai Upaya Penatalaksanaan Hipertensi di Posyandu Lansia, Jurnal Ilmiah Kebidanan Bidan Prada, 2(9): 138-148

Intarti WD, Savitri NPH, 2021, Manfaat Relaksasi Yoga dan Swedish Massage terhadap Stres Lansia saat Pandemi Covid19, Jurnal Bina Cipta Husada: 1(17): 96-112

Jahja Y, 2011, Psikologi perkembangan. Jakarta: Prenada Media.

Nurlila dan Fua, 2020, Jahe Peningkat Sistem Imun Tubuh di Era Pandemi Covid-19 di Kelurahan Kadia Kota Kendari, Jurnal Mandala, 1(2): 54-61

Panduan Perlindungan Lanjut Usia Berperspektif Gender Pada Masa Covid-19 Deputi Bidang Perlindungan Hak Perempuan Kementerian Pemberdayaan Perempuan Dan Perlindungan Anak Republik Indonesia. 2020. melalui https://infeksiemerging.kemkes.go.id/downlo ad/Panduan_Perlindungan_Lanjut_Usia_Ber perspektif Gender Pada Masa COVID19.pdf

Pertiwi dkk, 2020, Pemanfaatan Tanaman Obat Keluarga (TOGA) Meningkatkan Imunitas Tubuh sebagai Pencegahan COVID-19, Jurnal Ilmiah Pengembangan dan Penerapan IPTEKS, 18(2): $110-118$ DOI: 10.33369/dr.v18i2.12665

Ritanti R dan Sari A, 2019, Swedish massage sebagai Intervensi Keperawatan Inovasi dalam Menurunkan Tekanan Darah pada 
Lansia HIpertensi, Jurnal Aisyiyah Merdeka: Stikes Aisyiyah Palembang 5(1): 12-21

Supa'at I, Zakaria Z, Maskon O, Aminuddin A, Nordin NAMM. 2013. Effects of Swedish Massage Therapy on Blood Pressure, Heart rate, and Inflammatory Markers in Hypertensive Women. Evidence-Based Complementary and Alternative Medicine. Vol 2013, Article ID 171852,:1-9. Alamat Link; http://dx.doi.org/10.1155/2013/171852

Suparmi, \& Wulandari, A. 2012. Herbal Nusantara 1001 Ramuan Tradisional Asli Indonesia. Yogyakarta: Andi Offset.

Wahyuningsih Z, Nugroho S, Mu'ah. Hubungan cemas dengan peningkatan tekanan darah pada pasien pre operasi di Ruang Bourgenvil RSUD DR.Soegiri Lamongan. Surya 2011; VIII(01): 53-9.

Windaryanti, R dan Riska, H. 2019. Terapi Komplementer Pelayanan kebidanan Berdasarkan Bukti Scientific dan Empiris. Yogyakarta: Deepublish.

World Health Organization. Coronavirus. Centers for Disease Control and Prevention. 2020. Coronavirus Disease 2019 (COVID19). People at Risk for Serious Illness from COVID-19. 